\title{
Control of the Acute Phase Response
}

\author{
SERUM C-REACTIVE PROTEIN KINETICS AFTER \\ ACUTE MYOCARDIAL INFARCTION
}

\author{
Irving Kushner, Martin L. Broder, and David Karp, Department of \\ Medicine, Case Western Reserve University School of Medicine at Metropolitan \\ General Hospital, Cleveland, Ohio 44109
}

\begin{abstract}
A B S T RAC T In order to investigate the magnitude and kinetics of the $\mathrm{C}$-reactive protein $(\mathrm{CRP})$ response after differing degrees of tissue injury, we studied changes in serum concentration of this acute phase protein in 19 patients after mild or extensive acute myocardial infarction. An increase in serum CRP concentration was seen in all patients. The rate of increase in concentration was found to be exponential, with a mean hourly rate constant for the entire group of patients of 0.085 (doubling time, $8.2 \mathrm{~h}$ ). Patients with extensive infarction attained mean serum CRP levels about 4 times as great as did patients with mild infarction. No difference could be shown in the mean rate constant between these groups, the greater CRP response in the former group resulting principally from a more protracted period of rise in serum CRP concentration. A lag period before serum CRP levels began to rise was noted in only 4 of the 13 patients in whom this could be assessed. 7 of 10 patients with presumed unstable angina (coronary insufficiency) showed no rise in CRP concentration, while a small increase as noted in 3 patients. The data suggest that acute tissue injury, such as myocardial infarction, rapidly leads to acceleration in synthesis of CRP, and that the duration of this period of acceleration is related to the extent of tissue injury.
\end{abstract}

\section{INTRODUCTION}

Tissue injury and inflammation result in a marked increase in synthesis of a number of plasma proteins, referred to as the acute phase response (1). C-reactive protein $(\mathrm{CRP})^{1}$ is noteworthy among these proteins

A preliminary report of a portion of this work has appeared in abstract form (1972. Clin. Res. 20: 794).

Received for publication 10 March 1977 and in revised form 1 August 1977.

'Abbreviations used in this paper: CRP, C-reactive protein; LDH, lactic dehydrogenase; SGOT, serum glutamic oxaloacetic transaminase. for the rapidity and magnitude of the rise in its serum concentration after many stimuli (2), including acute myocardial infarction (3-5). A number of recent reports have indicated that CRP may play a significant functional role in modulating inflammatory and immune responses after tissue injury: The complement cascade can be activated by the reaction between CRP and a variety of substrates (6-8); and CRP suppresses platelet function (9), binds to T lymphocytes, and inhibits certain lymphocyte functions (10).

Although it is known that CRP and the other acute phase proteins are synthesized primarily by liver $(1,11,12)$, the mechanisms leading to the acute phase response, and particularly the CRP response, are poorly understood (1). In the present work, we estimated the kinetics of rise in serum CRP concentration after acute myocardial infarction in order to gain insight into these mechanisms. In addition, we compared the magnitude of the CRP response in patients with extensive and with mild degrees of myocardial necrosis, in order to explore the relationship between extent of tissue injury and the magnitude and kinetics of changes in serum CRP concentration, and by inference (13), of CRP formation.

\section{METHODS}

Study subjects. Patients admitted to the cardiac care unit of Cleveland Metropolitan General Hospital were studied. An initial blood sample was taken when the decision to admit the patient was made, generally in the emergency room. Subsequent samples were taken approximately $2,4,8$, $12,18,24,36,48$, and $72 \mathrm{~h}$ afterwards when possible, and at 5 and 7 days. Samples were most frequently obtained through an indwelling central venous pressure line which was appropriately rinsed before specimens were withdrawn; samples were then stored at $4^{\circ} \mathrm{C}$ for $1-2$ days until centrifuged. Serum was stored at $-20^{\circ} \mathrm{C}$. White blood counts and serum enzyme concentrations were determined daily during the first 5 days by the hospital's routine clinical laboratory, using standard methods $(14,15)$. Normal values were lactic dehydrogenase $(\mathrm{LDH})$, less than $350 \mathrm{U}$; heat- 
stable LDH, 30-60\% of total; and glutamic oxaloacetic transaminase (SGOT), less than $40 \mathrm{U}$.

By World Health Organization criteria, 19 patients were found to have definite acute myocardial infarction based on typical history, unequivocal electrocardiographic changes, and elevation in LDH and SGOT concentrations (16). In 10 cases which did not meet these criteria, a clinical diagnosis of unstable angina (coronary insufficiency) was provisionally made; although mild increases in LDH concentration were noted in several instances, electrocardiographic changes of infarction were not found and history was often atypical.

Patients with infarction were divided into two groups on the basis of rough estimates of the amount of myocardial tissue necrosis (Table I). Patients with maximum serum LDH concentrations over $1,000 \mathrm{U}$ were classified as having extensive infarction, whereas lesser concentrations were considered to indicate mild infarction. 11 patients fell into the former group, all with LDH concentrations greater than 1,400 units, while the 8 patients in the latter group all had less than $900 \mathrm{U}$. Determination of heat stable-LDH revealed a comparable difference, with no overlap between the groups. Other criteria of severity (SGOT concentration, maximum temperature, and maximum white blood count) similarly differed significantly between the two groups (Table J.).

TABLE I

Clinical and Laboratory Findings in Patients with Acute Myocardial Infarction

\begin{tabular}{|c|c|c|c|c|c|}
\hline \multirow[b]{2}{*}{ Patient } & \multicolumn{2}{|c|}{ Maximum LDH } & \multirow[b]{2}{*}{$\begin{array}{l}\text { Maximum } \\
\text { SGOT }\end{array}$} & \multirow{2}{*}{$\begin{array}{l}\text { Maximum } \\
\text { tempera- } \\
\text { ture }\end{array}$} & \multirow{2}{*}{$\begin{array}{c}\text { Maximum } \\
\text { white } \\
\text { blood } \\
\text { count }\end{array}$} \\
\hline & Total & $\begin{array}{l}\text { Heat- } \\
\text { stable }\end{array}$ & & & \\
\hline & $U$ & $U$ & $U$ & ${ }^{\circ} \mathrm{C}$ & cells $/ \mathrm{mm}^{3}$ \\
\hline \multicolumn{6}{|c|}{$\begin{array}{l}\text { Extensive } \\
\text { infarction }\end{array}$} \\
\hline 1 & 4,250 & 2,675 & 700 & 39.5 & 19,300 \\
\hline 2 & 2,150 & 450 & 260 & 40.5 & 21,700 \\
\hline 3 & 1,450 & 620 & 266 & 37.0 & 11,000 \\
\hline 4 & 1,450 & 950 & 138 & 38.5 & 12,300 \\
\hline 5 & 1,950 & 885 & 226 & 37.6 & 12,100 \\
\hline 6 & 2,600 & 1,625 & 490 & 38.1 & 14,100 \\
\hline 7 & 1,960 & 1,060 & 215 & 38 & 19,400 \\
\hline 8 & 2,750 & 1,530 & 112 & 38.5 & 11,600 \\
\hline 9 & 2,100 & 1,350 & 290 & 38 & 14,700 \\
\hline 10 & 2,575 & 905 & 160 & 37.5 & 11,900 \\
\hline 11 & 2,420 & 1,500 & 144 & 38.5 & 11,400 \\
\hline Mean & 2,330 & 1,232 & 273 & 38.3 & 14,500 \\
\hline SEM & \pm 231 & \pm 184 & \pm 53 & \pm 0.3 & $\pm 1,155$ \\
\hline \multicolumn{6}{|c|}{$\begin{array}{l}\text { Mild } \\
\text { infarction }\end{array}$} \\
\hline 12 & 385 & 160 & 34 & 37.5 & 8,900 \\
\hline 13 & 780 & 275 & 140 & 37.5 & 12,600 \\
\hline 14 & 690 & 345 & 86 & 37.3 & 12,000 \\
\hline 15 & 615 & 265 & 52 & 37 & 5,600 \\
\hline 16 & 640 & 300 & 106 & 37.3 & 7,700 \\
\hline 17 & 380 & 200 & 60 & 37.5 & 5,500 \\
\hline 18 & 645 & 375 & 25 & 37.8 & 14,300 \\
\hline 19 & 810 & 325 & 79 & 37.4 & 16,600 \\
\hline Mean & 618 & 280 & 73 & 37.4 & 10,360 \\
\hline SEM & \pm 57 & \pm 26 & \pm 13 & \pm 0.08 & $\pm 1,436$ \\
\hline$P$ value & $<0.001$ & $<0.001$ & $<0.005$ & $<0.01$ & $<0.05$ \\
\hline
\end{tabular}

Additional clinical criteria reflecting the hemodynamic consequences of extensive infarction, transient hypotension, or heart failure were noted in 9 patients in the extensive infarction group and in 2 patients with mild infarction.

Estimation of CRP response. Serum CRP concentrations were determined in triplicate by a radial immunodiffusion technique (17), sensitive to $1.5 \mu \mathrm{g} / \mathrm{ml}$. The magnitude of the CRP response was estimated from the highest serum CRP concentration observed. Although it would have been optimal to estimate CRP response from either the increase in concentration over base-line values or by integrating the curve of CRP concentration against time (18), neither of these methods was possible. Base-line values, of necessity, could not be obtained, and CRP concentration often did not return to initial values during the period of study.

\section{RESULTS}

Serum CRP kinetics. We were able to study the kinetics of the change in serum CRP concentration in the 10 patients with extensive infarction and in 4 of the 5 patients with mild infarction from whom sample collection was begun $9 \mathrm{~h}$ or less after onset of chest pain (Table II). In 6 of these patients, the first sample was obtained as early as $2.5 \mathrm{~h}$ or less after chest pain. In every case, a plot of log CRP concentration against time revealed a phase of exponential increase, followed by a slowing in rate of rise and finally a decrease in concentration. This pattern was observed in patients with both extensive (Fig. 1) and mild (Fig. 2) infarction. Comparable findings were noted in one additional patient with mild infarction (case 17) whose first sample was obtained $18 \mathrm{~h}$ after onset of pain. Observed double times during the exponential phase varied widely in both groups. The average value for the entire population was $8.2 \mathrm{~h}$; a difference could not be shown between the two groups. The hourly rate constant, $a=\ln 2 /$ doubling time, ranged from 0.050 to 0.177 , with an average value of 0.085 .

Lag period. No lag period before rise in serum concentration was noted in 9 of the 15 patients whose first sample was obtained within $9 \mathrm{~h}$ of the onset of pain. In 2 patients (cases 13 and 16) we could not tell whether there was a lag or not, since CRP concentrations were too low in the initial samples to be accurately measured. In the remaining 4 patients ( 3 with extensive and 1 with mild infarction) a definite lag period was noted, serum CRP concentrations not beginning their rise until 12-22 $\mathrm{h}$ after onset of pain (Fig. 3). Maximal SGOT and LDH concentrations were reached in these patients at approximately the same time after onset of pain as in patients who did not show a lag period. There was no clinical evidence of liver disease in these patients. Doubling time was significantly slower in these 4 patients, averaging $10.7 \pm 3.1 \mathrm{~h}$ compared with $7.3 \pm 2.5 \mathrm{~h}$ in the 11 patients without demonstrable lag $(P<0.025)$.

Comparison of patients with extensive and mild 
TABLE II

CRP Response to Acute Myocardial Infarction

\begin{tabular}{|c|c|c|c|c|c|c|}
\hline \multirow[b]{2}{*}{ Patient } & \multicolumn{2}{|c|}{ First sample } & \multirow[b]{2}{*}{$\begin{array}{l}\text { Maximum observed } \\
\text { CRP concentration }\end{array}$} & \multirow[b]{2}{*}{$\begin{array}{l}\text { Time from pain } \\
\text { until peak CRP } \\
\text { concentration }\end{array}$} & \multirow[b]{2}{*}{$\begin{array}{l}\text { Doubling } \\
\text { time }\end{array}$} & \multirow[b]{2}{*}{$\begin{array}{l}\text { Lag phase } \\
\text { duration } \\
\text { after pain }\end{array}$} \\
\hline & $\begin{array}{c}\text { Time after } \\
\text { pain }\end{array}$ & $\begin{array}{c}\text { Serum CRP } \\
\text { concentration }\end{array}$ & & & & \\
\hline & $h$ & $\mu g / m l$ & $\mu g / m l$ & $h$ & $h$ & $h$ \\
\hline \multicolumn{7}{|c|}{$\begin{array}{l}\text { Extensive } \\
\text { infarction }\end{array}$} \\
\hline 1 & 1 & 4.5 & 110.5 & 51.5 & 4.6 & * \\
\hline 2 & 1.5 & 6.7 & 190.4 & 97.0 & 5.5 & $*$ \\
\hline 3 & 2.5 & 5.2 & 77.2 & 75.5 & 12.0 & 12 \\
\hline 4 & 3 & 6.9 & 206.6 & 75.5 & 6.5 & 12 \\
\hline 5 & 3 & 1.8 & 98.6 & 75.5 & 7.3 & $*$ \\
\hline 6 & 3 & 8.0 & 84.3 & 51.0 & 9.4 & * \\
\hline 7 & 3.5 & 6.4 & 166.6 & 74.5 & 10.8 & $*$ \\
\hline 8 & 5 & 1.8 & 169.3 & 77.0 & 4.5 & * \\
\hline 9 & 8 & 4.6 & 140.7 & 74.5 & 8.7 & $*$ \\
\hline 10 & 9 & 32.0 & 260.4 & 81 & 13.7 & 22 \\
\hline 11 & 60 & 61.3 & 248.2 & 94.5 & $\$$ & $\ddagger$ \\
\hline Mean & & & 159.4 & 75.2 & 8.3 & \\
\hline SEM & & & \pm 19.1 & \pm 4.3 & \pm 1.0 & \\
\hline \multicolumn{7}{|c|}{$\begin{array}{l}\text { Mild } \\
\text { infarction }\end{array}$} \\
\hline 12 & 2 & 1.7 & 83.0 & 38 & 3.9 & * \\
\hline 13 & 2 & $<1.5$ & 13.6 & 38 & 6.4 & $t$ \\
\hline 14 & 2 & 5.6 & 43.3 & 48 & 10.8 & 17 \\
\hline 15 & 5.5 & 27 & 34.0 & 41.5 & 9.8 & $*$ \\
\hline 16 & 7.5 & $<1.5$ & 4.1 & 52.5 & $\$ \S$ & $\ddagger$ \\
\hline 17 & 18 & 3.8 & 10.0 & 37.5 & 9.8 & $t$ \\
\hline 18 & 29 & 65.2 & 93.2 & 47 & $\neq$ & $\downarrow$ \\
\hline 19 & Uncertain & 9.0 & 35.4 & + & $\dot{t}$ & $t$ \\
\hline Mean & & & 39.4 & 43.2 & 8.1 & \\
\hline SEM & & & \pm 11.7 & \pm 2.2 & \pm 1.3 & \\
\hline$P$ value & & & $<0.001$ & $<0.001$ & NS & \\
\hline
\end{tabular}

* None noted.

$\$$ Could not be ascertained from available data.

$\S$ CRP concentration too low to be accurately measured until $43.5 \mathrm{~h}$ after pain.

infarction. Features of the CRP response in the two groups with infarction are compared in Table II. It was possible to determine the concentration and timing of the maximal serum CRP level in all 19 patients. Average peak serum CRP concentrations were about 4 times as great in 11 patients with extensive infarction as in 8 patients with mild infarction. Regression curves plotting maximum CRP against maximum enzyme levels for individual patients showed a correlation of CRP with maximum total LDH ( $P$ $<0.01)$ and heat-stable LDH $(P<0.05)$, but not with SGOT. No correlation between maximum enzyme levels and CRP doubling times was found.

The difference in maximal CRP levels did not appear to result from more rapid rates of increase in concentration, since the groups could not be shown to differ significantly in mean doubling time. However, because considerable variation in doubling times was found in each group, we further compared the rate of rise in serum CRP concentration, using the relationship between $\log$ serum concentration and time as expressed by a rate formula developed to fit the middle $80 \%$ of the linear portions of the curves. Applying the formula $d \mathrm{C}_{\mathrm{t}} / d \mathrm{t}=\mathrm{C}_{0} a \mathrm{e}^{a t}$, where $\mathrm{C}_{\mathrm{t}}$ is CRP concentration at time $t$ after onset of chest pain, $\mathrm{C}_{0}$ is initial concentration, and $a$ is the rate constant, the initial rate of rise in serum CRP concentration could be calculated for each of the 15 patients whose rate constant was ascertainable. The calculated mean initial rate of increase in concentration for the mild infarction group was $0.116 \mu \mathrm{g} / \mathrm{ml}$ per $\mathrm{h}(\mathrm{SD}=0.04)$ and for the extensive infarction group $0.270(\mu \mathrm{g} / \mathrm{ml}$ 

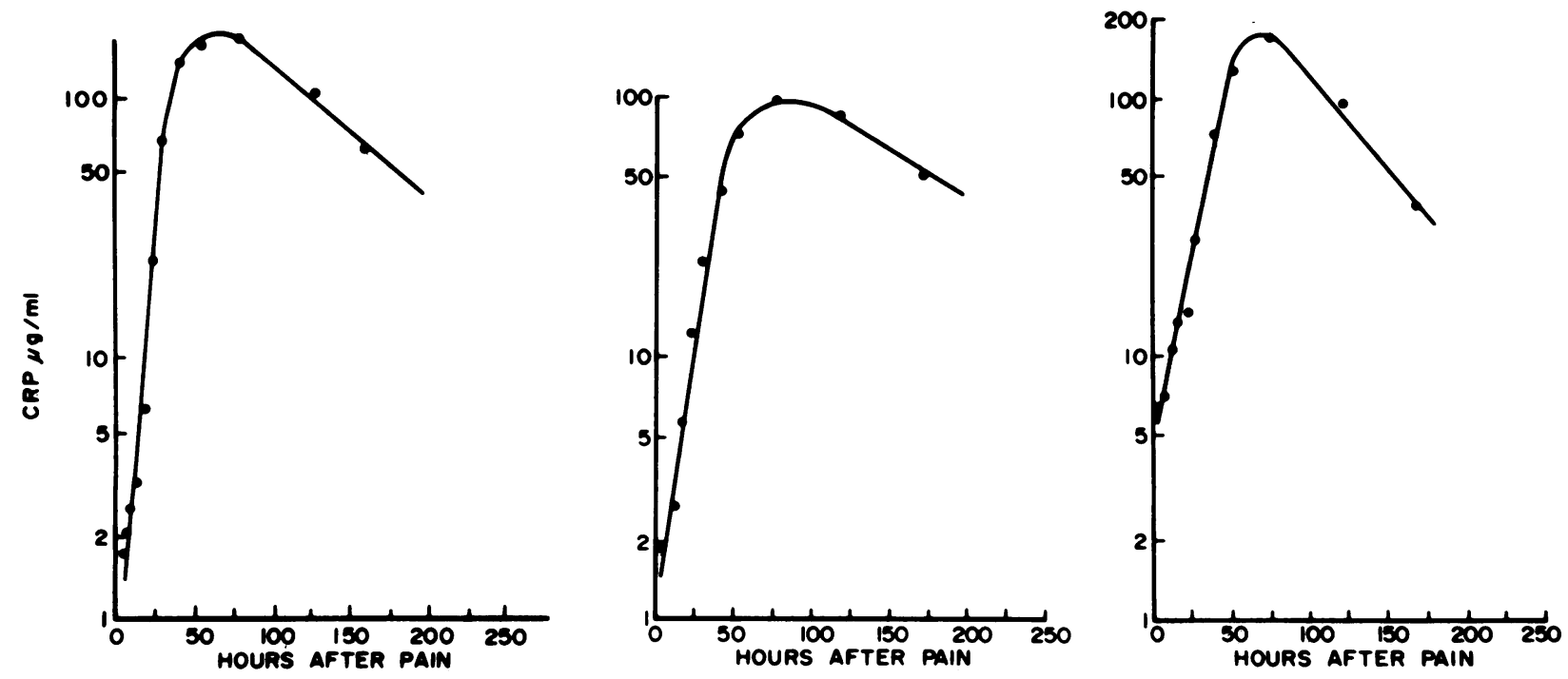

FIGURE 1 Semilogarithmic plot of serum CRP concentrations after chest pain in three representative patients (Nos. 8, 5, and 7) with extensive acute myocardial infarction.

per $\mathrm{h}(\mathrm{SD}=0.18)$. This difference did not achieve significance $(0.10>P>0.05)$.

In contrast, a highly significant difference in duration of the period of rising serum CRP concentration was noted; in mild infarction, concentrations continued to increase for nearly 2 days before falling, while in extensive infarction, serum CRP concentrations did not reach a maximum, on the average, until more than 3 days after pain.
Unstable angina patients. The clinical characteristics of the patients with the provisional diagnosis of unstable angina are shown in Table III. In three patients (Nos. 20-22), serum CRP concentration never attained detectable levels. In four patients (Nos. 23-26), followed for 2.5-10 days after onset of pain, no significant increases in concentration were noted in serial samples, serum CRP concentrations remaining at fairly constant levels in the range of $25,18,5.5$, and

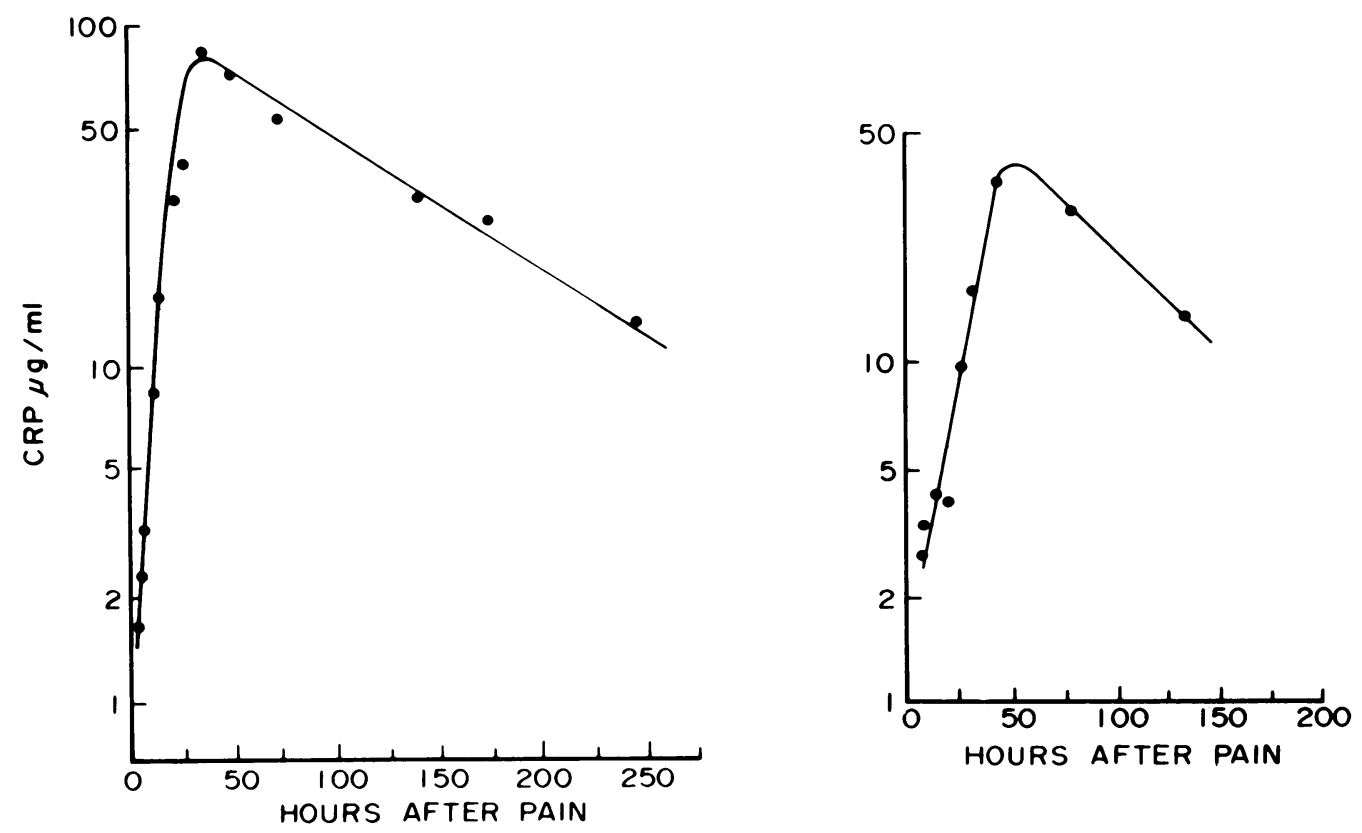

FIGURE 2 Semilogarithmic plot of serum CRP concentrations after chest pain in two representative patients (Nos. 12 and 15) with mild acute myocardial infarction. 

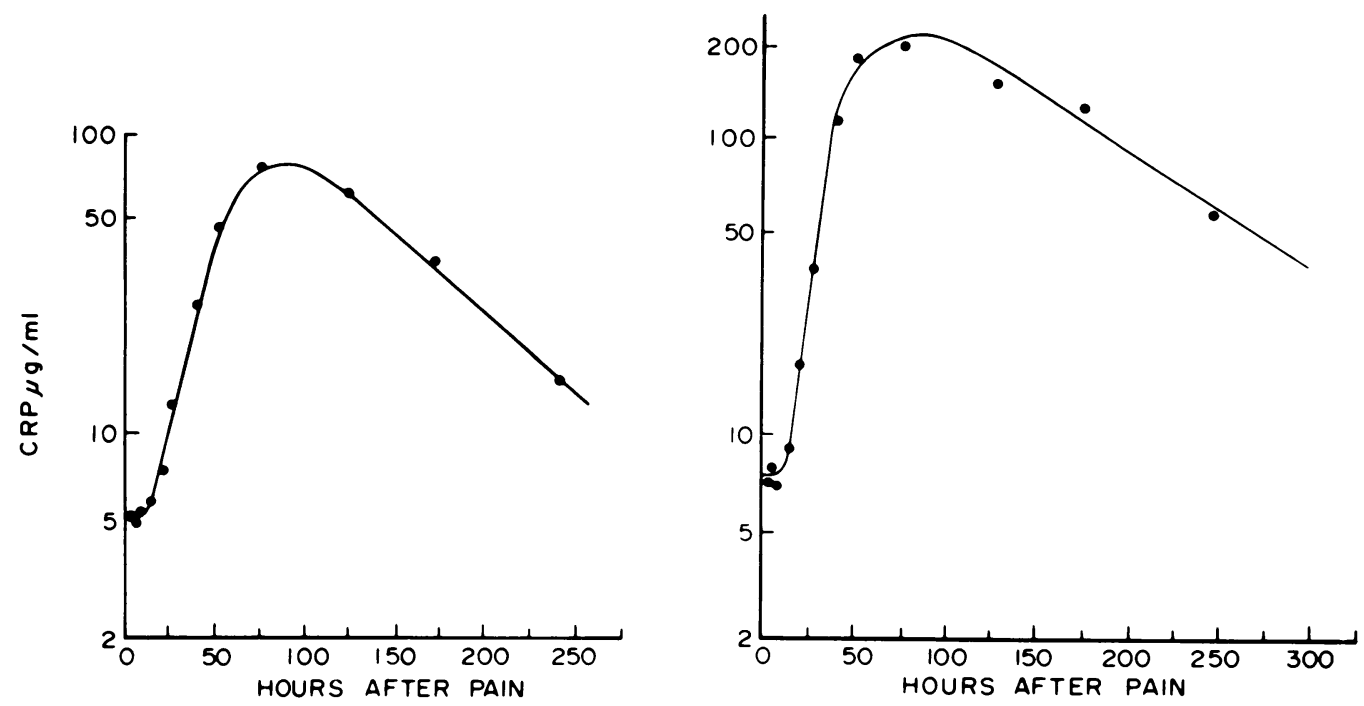

FIGURE 3 Lag period preceding increase in serum CRP concentration in two patients (Nos. 3 and 4) with severe acute myocardial infarction.

$3.5 \mu \mathrm{g} / \mathrm{ml}$. In three patients, a significant rise in CRP concentration was noted (Table IV).

\section{DISCUSSION}

Previously held beliefs that CRP is normally absent in serum, appearing only in response to inflammatory stimuli, are no longer tenable since the demonstration that CRP can be detected in the serum of all normal human subjects tested $(19,20)$. This finding implies that CRP formation normally occurs at low rates and is increased by tissue injury. The current study indicates that myocardial infarction results in a rapid exponential increase in serum concentration of CRP, that this increase usually begins within a few hours after pain, and that its magnitude is related to the degree of tissue injury.

TABLE III

Clinical and Laboratory Findings in Patients with Unstable Angina (Coronary Insufficiency)

\begin{tabular}{|c|c|c|c|c|c|c|}
\hline \multirow[b]{2}{*}{ Patient } & \multicolumn{2}{|c|}{$\begin{array}{l}\text { Maximum } \\
\text { LDH }\end{array}$} & \multirow[b]{2}{*}{$\begin{array}{l}\text { Maximum } \\
\text { SGOT }\end{array}$} & \multirow[b]{2}{*}{$\begin{array}{l}\text { Maximum } \\
\text { temperature }\end{array}$} & \multirow[b]{2}{*}{$\begin{array}{l}\text { Maximum white } \\
\text { cell count }\end{array}$} & \multirow[b]{2}{*}{ Electrocardiographic findings } \\
\hline & Total & $\begin{array}{l}\text { Heat- } \\
\text { stable }\end{array}$ & & & & \\
\hline & $U$ & $U$ & $U$ & ${ }^{\circ} \mathrm{C}$ & cells $/ \mathrm{mm}^{3}$ & \\
\hline 20 & 395 & 150 & 15 & 36.8 & 6,800 & Nonspecific ST changes \\
\hline 21 & 425 & 215 & 31 & 36.8 & 7,100 & Anteroseptal ischemia \\
\hline 22 & 500 & 162 & 34 & 36.9 & 5,700 & Nonspecific ST changes \\
\hline 23 & 580 & 275 & 26 & 37.5 & 11,200 & Old anteroseptal infarction \\
\hline 24 & 365 & 105 & 46 & 37.2 & 11,600 & Nonspecific ST changes \\
\hline 25 & 475 & 210 & 28 & 36.8 & 12,900 & Old inferior wall infarction \\
\hline 26 & 425 & 140 & 49 & 36.7 & 6,800 & LVH and strain, inferolateral injury \\
\hline 27 & 650 & 225 & 44 & 37.5 & 5,900 & $\begin{array}{l}\text { Junctional rhythm, subendocardial } \\
\text { injury, and ischemia }\end{array}$ \\
\hline 28 & 320 & 90 & 23 & 36.8 & 9,300 & $\begin{array}{l}\text { Paroxysmal atrial fibrillation, tran- } \\
\text { sient lateral subendocardial injury }\end{array}$ \\
\hline 29 & 525 & 221 & 47 & 37.1 & 9,500 & LVH and strain \\
\hline
\end{tabular}


TABLE IV

CRP Response in Three Patients with Unstable Angina

\begin{tabular}{ccccccc}
\hline & \multicolumn{2}{c}{ First sample } & & & & Time from pain \\
Patient & $\begin{array}{c}\text { Time after } \\
\text { pain }\end{array}$ & $\begin{array}{c}\text { Serum CRP } \\
\text { concentration }\end{array}$ & $\begin{array}{c}\text { Maximum observed } \\
\text { CRP concentration }\end{array}$ & $\begin{array}{c}\text { until peak CRP } \\
\text { concentration }\end{array}$ & $\begin{array}{c}\text { Doubling } \\
\text { time }\end{array}$ & $\begin{array}{c}\text { duration } \\
\text { after pain }\end{array}$ \\
\hline & $h$ & $\mu g / m l$ & $\mu g / m l$ & $h$ & $h$ & $h$ \\
27 & Uncertain & 4.6 & 12.9 & $*$ & 16 & $\$$ \\
28 & 21 & 4.1 & 11.6 & 45 & 13.5 & 27 \\
29 & 17 & 3.0 & 17.0 & 53 & 7 & + \\
\hline
\end{tabular}

* Could not be ascertained from available data.

$\ddagger$ None noted.

We have noted comparable curves of increase in serum CRP concentration after such diverse insults as acute dissecting aneurysm, bone fracture, and a variety of surgical procedures. In rabbits, similar changes were seen after i.v. administration of endotoxin (18) and i.m. injection of typhoid vaccine or turpentine. Such findings indicate that these kinetics may result from a large variety of stimuli leading to tissue necrosis and suggest that a common mechanism is responsible for the CRP response in each case.

Since localized inflammatory processes distant from the liver result in increased synthesis of CRP (21), it is presumed that a circulating mediator is responsible for increase in hepatic CRP synthesis after stimulation (1). Early studies of the CRP response (22), in which relatively insensitive capillary precipitin tests were used, suggested that a lag period of 6-8 h preceded appearance of CRP in serum. The present study, using a more sensitive technique (23), demonstrated that the rise in CRP concentration usually begins much earlier, within 1 or $2 \mathrm{~h}$ after chest pain, suggesting relatively rapid formation of mediator. Although it is possible that the onset of chest pain may not coincide with the onset of tissue injury, the finding in rabbits that an exponential increase in serum CRP concentration usually began within the first hour after endotoxin administration (18) suggests that a similarly brief lag period occurred in the patients here reported.

In 4 of the 15 patients from whom the first sample was obtained within $9 \mathrm{~h}$ of the onset of pain, a lag period of up to $22 \mathrm{~h}$ was observed before serum concentration began to rise. This phenomenon was noted in patients with both mild and extensive infarction, indicating no relationship to extent of tissue injury. However, the subsequent rate of rise in serum concentration was significantly slower in patients showing lag. This finding suggests either sluggish hepatic response or slow or subnormal mediator formation after stimulus. Alternatively, tissue injury may not have coincided with onset of pain.

In the current experiments, rates of rise in serum CRP level varied widely, rate constants ranging be- tween 0.050 and 0.177 , but could not be shown to be significantly related to extent of necrosis. Because of the wide variations in rate constants we observed, these findings cannot conclusively rule out the possibility that such a relationship might exist. However, in both this study and a study of the rabbit CRP response after endotoxin administration (18), the magnitude of the CRP response was clearly related to duration of the period during which serum CRP level continued to rise, suggesting that extensive tissue necrosis is associated with more prolonged production or persistence of the postulated mediator.

During acceleration, the actual rates of synthesis are constantly changing and cannot readily be measured directly by currently available techniques (24). Estimation of rates of synthesis and of acceleration from change in serum concentration is imprecise, as pointed out in another context (25), since it would fail to take into account the effect of extravascular diffusion and catabolism. However, if it is assumed that these factors are relatively minor during the early period of rapid increase in serum concentration (13), then changes in serum concentration, while not measuring precise rates, would reflect changes in CRP synthesis and secretion. Such considerations would suggest that the effect of mediator is to cause acceleration in rate of CRP synthesis.

The validity of drawing conclusions about hepatic synthetic rate from changes in serum concentration is supported by studies of synthesis of CRP by 15 isolated perfused livers from rabbits at intervals after inflammatory stimulus (26). In these studies, in which liver was no longer exposed to circulating mediator, CRP was synthesized at a linear (nonexponential) rate in each case, for periods of 3-8 h. Such perfusion experiments may be envisioned as samplings of actual synthetic rates at single points in time during the course of in vivo acceleration in rate. Observed rates of synthesis were exponentially related to duration of inflammation in vivo before isolation and perfusion of liver, with a mean doubling time of $7.7 \mathrm{~h}$, comparable to serum doubling times observed in both man and rabbits (18). 
Patients with acute myocardial infarction were selected as subjects for this study because the extent of tissue injury could be approximately assessed and because the time of onset of chest pain could be taken as a reasonably accurate and consistent estimate of the occurrence of tissue injury. While determination of serum concentrations of LDH, its cardiac isozymes, and SGOT does not permit precise estimation of extent of myocardial damage, the relationship between elevation of these enzymes and size of infarction is sufficiently valid for the semiquantitative needs of this study (27). Division into two groups appears empirically sound in the patients we studied, as shown by other evidences of tissue injury. Certainly the clearcut division between the two groups in heat-stable LDH activity, SGOT, temperature, white blood count, and hemodynamic consequences of myocardial disease attests to the validity of this separation.

Serum CRP was consistently found to rise in patients with myocardial infarction, while in the 10 patients presumed to have unstable angina, no rise was found in 7 patients and only a minimal rise in 3 others. It may be that these latter patients actually sustained mild myocardial necrosis, although this diagnosis could not be made by the clinical criteria we employed. In most cases, these patients presented to hospital many hours after onset of pain, compared to the patients with definite infarction. It may be that clinical, laboratory, and electrocardiographic studies, if begun earlier, would have permitted the diagnosis of infarction in these patients, as might myocardial scintigraphy, perfusion scanning, or creatine kinase isoenzyme studies, which were not performed in these patients. These findings suggest that serial studies of serum CRP concentration may prove of value in detecting patients with myocardial necrosis and distinguishing them from those without infarction. Such studies would require at least daily determinations for 2 or 3 days. Whether this information would be of more use than the newer diagnostic procedures mentioned above is uncertain at this time.

\section{ACKNOWLEDGMENTS}

We are grateful for the technical assistance of William $\mathrm{N}$. Ribich and the secretarial excellence of Mrs. Helen Morrison. The invaluable cooperation of the nursing staff and house staff of the Cardiac Care Unit at Cleveland Metropolitan General Hospital is gratefully acknowledged.

This work was supported by U. S. Public Health Service grants AI 08366 and AI 12886 and by The American Heart Association, Northeastern Ohio Chapter, Inc.

\section{REFERENCES}

1. Koj, A. 1974. Acute phase reactants. In Structure and Function of Plasma Proteins. A. C. Allison, editor, Plenum Publishing Corp., New York. 1: 73-125.

2. Kushner, I., T. S. Edgington, C. Trimble, H. H. Liem, and U. Muller-Eberhard. 1972. Plasma hemopexin homeostasis during the acute phase response. J. Lab. Clin. Med. 80: 18-25.

3. Hedlund, P. 1947. Appearance of acute phase protein in various diseases. Acta Med. Scand. Suppl. 196: $579-601$.

4. Losner, S., B. W. Volk, and S. M. Aronson. 1957. Diagnostic aids in acute myocardial infarction: clinical and experimental. Am. Heart J. 54: 22.5-234.

5. Johansson, B. G., C-O. Kindmark, E. Y. Trell, and F. A. Wollheim. 1972. Sequential changes of plasma proteins after myocardial infarction. Scand. J. Clin. Lab. Invest. 29(Suppl. 124): 117-126.

6. Kaplan, M. H., and J. E. Volanakis. 1974. Interaction of C-reactive protein complexes with the complement system. I. Consumption of human complement associated with the reaction of $\mathrm{C}$-reactive protein with pneumococcal $\mathrm{C}$-polysaccharide and with the choline phosphatides, lecithin and sphingomyelin. J. Immunol. 112: 2135-2147.

7. Siegal, J., R. Rent, and H. Gewurz. 1974. Interactions of C-reactive protein with the complement system. I. Protamine-induced consumption of complement in acute phase sera. J. Exp. Med. 140: 631-647.

8. Siegel, J., A. P. Osmand, M. F. Wilson, and H. Gewurz. 1975. Interactions of C-reactive protein with the complement system. II. C-reactive protein-mediated consumption of complement by poly-L-lysine polymers and other polycations. J. Exp. Med. 142: 709-721.

9. Marder, R. J., B. A. Fiedel, A. P. Osmand, and H. Gewurz. 1977. Inhibition of rabbit platelet aggregation and clot retraction by rabbit and human C-reactive proteins. Proc. Soc. Exp. Biol. Med. 155: 44-47.

10. Mortensen, R. F., D. Braun, and H. Gewurz. 1977. Effects of C-reactive protein on lymphocyte functions. III. Inhibition of antigen-induced lymphocyte stimulation and lymphokine production. Cell. Immunol. 28: 59-68.

11. Hurlimann, J., G. J. Thorbecke, and G. M. Hochwald. 1966. The liver as the site of $\mathrm{C}$-reactive protein formation. J. Exp. Med. 123: 365-378.

12. Kushner, I., and J. Somerville-Volanakis. 1976. Molecular size of rabbit C-reactive protein synthesized in vitro. J. Lab. Clin. Med. 87: 617-623.

13. Uhr, J. W., and M. S. Finkelstein. 1967. The kinetics of antibody formation. Prog. Allergy. 10: 37-83.

14. Hochella, N. J., and S. Weinhouse. 1965. Automated assay of lactate dehydrogenase in urine. Anal. Biochem. 13: 322-335.

15. Morgenstern, S., M. Oklander, J. Auerbach, J. Kaufman, and B. Klein. 1966. Automated determination of serum glutamic oxaloacetic transaminase. Clin. Chem. 12: 95111.

16. Myocardial Infarction Community Registers. 1976. Regional Office for Europe, World Health Organization, Copenhagen. 157-160.

17. Kushner, I., and J. A. Somerville. 1970. Estimation of the molecular size of C-reactive protein and Cx-reactive protein in serum. Biochim. Biophys. Acta. 207: 105-114.

18. Yen-Watson, B., and I. Kushner. 1974. Rabbit CRP response to endotoxin administration: dose-response relationship and kinetics. Proc. Soc. Exp. Biol. Med. 146: $1132-1136$

19. Kindmark, C-O., and J. I. Thorell. 1972. Quantitative determination of individual serum proteins by radioelectroimmunoassay and use of ${ }^{125}$ I-labelled antibodies (application to C-reactive protein). Scand. J. Clin. Lab. Invest. 29(Suppl. 124): 49-53.

20. Claus, D. R., A. P. Osmand, and H. Gewurz. 1976. 
Radioimmunoassay of human C-reactive protein and levels in normal sera. J. Lab. Clin. Med. 87: 120-128.

21. Kushner, I., and J. Somerville-Volanakis. 1973. Studies of synovial and serum C-reactive protein in experimental arthritis in rabbits. Proc. Soc. Exp. Biol. Med. 142: 112-114.

22. Boltax, A. J., and E. E. Fischel. 1956. Serologic tests for inflammation; serum complement, C-reactive protein and erythrocyte sedimentation rate in myocardial infarction. Am. J. Med. 20: 418-427.

23. Nilsson, L-A. 1968. Comparative testing of precipitation methods for quantitation of C-reactive protein in blood serum. Acta Pathol. Microbiol. Scand. 73: 129-144.
24. Tavill, A. S., and R. Hoffenberg. 1976. Turnover of plasma proteins. In Structure and Function of Plasma Proteins. A. C. Allison, editor. Plenum Publishing Corp., New York. 2: $107-144$.

25. Waldmann, T. A., and W. Strober. 1969. Metabolism of immunoglobulins. Prog. Allergy. 13: 1-110.

26. Kushner, I., W. N. Ribich, and J. B. Blair. 1976. How is $\mathrm{C}$-reactive protein (CRP) synthesis regulated? Studies in isolated perfused rabbit liver. In Protides of the Biological Fluids, XXIII Colloquium, Brugge, 1975. H. Peeters, editor. Pergamon Press, Elmsford, N. Y. 471-474.

27. Sobel, B. E., and W. E. Shell. 1972. Serum enzyme determinations in the diagnosis and assessment of myocardial infarction. Circulation. 45: 471-482. 